\title{
Isolation of sulfate-reducing bacteria from sediments above the deep-subseafloor aquifer
}

\section{Katja Fichtel, Falko Mathes ${ }^{\dagger}$, Martin Könneke ${ }^{\dagger}$, Heribert Cypionka and Bert Engelen* $^{*}$}

Paleomicrobiology, Institute for Chemistry and Biology of the Marine Environment, University of Oldenburg, Oldenburg, Germany

\section{Edited by:}

Andreas Teske, University of North

Carolina at Chapel, USA

\section{Reviewed by:}

Alexander Loy, University of Vienna,

Austria

Julia Maresca, University of

Delaware, USA

\section{*Correspondence:}

Bert Engelen, Paleomicrobiology, Institute for Chemistry and Biology of the Marine Environment,

Carl-von-Ossietzky-Straße 9-11, 26129

Oldenburg, Germany.

e-mail:engelen@icbm.de

\section{${ }^{\dagger}$ Present address:}

Falko Mathes, School of Earth and Ocean Sciences, Cardiff University, Cardiff, UK.;

Martin Könneke, Max Planck Institute for Marine Microbiology, Bremen, Germany.
On a global scale, crustal fluids fuel a large part of the deep-subseafloor biosphere by providing electron acceptors for microbial respiration. In this study, we examined bacterial cultures from sediments of the Juan de Fuca Ridge, Northeast Pacific (IODP Site U1301). The sediments comprise three distinctive compartments: an upper sulfate-containing zone, formed by bottom-seawater diffusion, a sulfate-depleted zone, and a second ( $140 \mathrm{~m}$ thick) sulfatecontaining zone influenced by fluid diffusion from the basaltic aquifer. In order to identify and characterize sulfate-reducing bacteria, enrichment cultures from different sediment layers were set up, analyzed by molecular screening, and used for isolating pure cultures. The initial enrichments harbored specific communities of heterotrophic microorganisms. Strains affiliated to Desulfosporosinus lacus, Desulfotomaculum sp., and Desulfovibrio aespoeensis were isolated only from the top layers (1.3-9.1 meters below seafloor, mbsf), while several strains of Desulfovibrio indonesiensis and a relative of Desulfotignum balticum were obtained from near-basement sediments (240-262 mbsf). Physiological tests on three selected strains affiliated to $D v$. aespoeensis, Dv. indonesiensis, and Desulfotignum balticum indicated that all reduce sulfate with a limited number of short-chain $n$-alcohols or fatty acids and were able to ferment either ethanol, pyruvate, or betaine. All three isolates shared the capacity of growing chemolithotrophically with $\mathrm{H}_{2}$ as sole electron donor. Strain P23, affiliating with $D v$. indonesiensis, even grew autotrophically in the absence of any organic compounds. Thus, $\mathrm{H}_{2}$ might be an essential electron donor in the deep-subseafloor where the availability of organic substrates is limited. The isolation of non-sporeforming sulfate reducers from fluid-influenced layers indicates that they have survived the long-term burial as active populations even after the separation from the seafloor hundreds of meters above.

Keywords: Desulfovibrio, Desulfotignum, diversity, deep biosphere, Juan de Fuca Ridge, hydrogen, chemolithoautotrophy, IODP

\section{INTRODUCTION}

The subseafloor biosphere is probably the largest reservoir for prokaryotic life on Earth (Whitman et al., 1998; Heberling et al., 2010). It extends several hundred meters into deeply buried sediments (Parkes et al., 1994; Roussel et al., 2008) and even further down into the upper layers of the oceanic crust (Thorseth et al., 1995; Furnes and Staudigel, 1999; Ehrhardt et al., 2007). Recently, it was estimated that the ocean crust contains a similar amount of microorganisms as the entire volume of the world's oceans (Heberling et al., 2010). The continuous circulation of seawater within the upper crust turns these voluminous, porous, and permeable basalts into the largest globally connected aquifer (Johnson and Pruis, 2003; Johnson et al., 2006).

Intense fluid circulation is a consequence of specific geological settings evolved during crust formation at ocean-spreading centers. It is especially pronounced at ocean ridges such as the Juan de Fuca Ridge in the Northeast Pacific (Johnson et al., 2006). This area is one of the most intensively studied locations in terms of heat-driven fluid flow (Fisher et al., 2003; Hutnak et al., 2006). While cold bottom-seawater is recharged at seamounts, it warms up within the oceanic crust beneath the sediments before being discharged again at other rocky outcrops exposed at the seafloor. The chemical composition of these low-temperature hydrothermal fluids $\left[<150^{\circ} \mathrm{C}\right.$ (Cowen, 2004)] is altered during long-term circulation through the basalt due to continuous abiotic waterrock interaction (Edwards et al., 2003) especially with increasing basement temperature (Wheat and Mottl, 1994; Wheat et al., 2000), or as a response to volcanic eruption (Butterfield et al., 1997). Additionally, microbial activity of crust-hosted communities contributes to changes in fluid composition by removing seawater constituents such as sulfate as indicated by sulfur-isotope measurements (Rouxel et al., 2008). However, due to a limitation in electron donors, crustal fluids are not fully reduced and still contain suitable electron acceptors, such as sulfate, for anaerobic respiration (Wheat and Mottl, 1994; Wheat et al., 2000; Cowen et al., 2003; Edwards et al., 2005).

It was postulated that basement fluids not only supply electron donors and acceptors to microbial life within the crust, but also to the microbial communities in the overlying sediments by diffusion from below (Cowen et al., 2003; DeLong, 2004; D'Hondt 
et al., 2004). We tested this hypothesis during an expedition to the eastern flank of the Juan de Fuca Ridge (IODP Exp. 301) by analyzing a 265-m-long sediment column of IODP site U1301. Sampling included material taken only two meters above the sediment-basement interface (Expedition 301 Scientists, 2005). At this site, sulfate diffuses into the sediments from both the seafloor ( $\sim 27 \mathrm{mM})$ and the underlying basement $(\sim 16 \mathrm{mM})$. As a precondition for a sound microbiological and geochemical analysis, contamination controls were performed directly onboard the drillship JOIDES Resolution and proved the pristine character of the sediment samples (Lever et al., 2006).

Our previous work has shown that fluids from the oceanic crust do support microbial life in the overlying sediments (Engelen et al., 2008). Exoenzyme activities and sulfate reduction rates were not only elevated near the seafloor but also at the bottom of the sediment column which correlated well with the overall geochemical settings. We detected enhanced microbial abundance in sediment layers above the basement by direct counting and the cultivationbased most probable number (MPN) technique. Microbial growth in anoxic MPN dilution series from sediment layers near the oceanic crust indicated considerable amounts of viable microbial populations. Thus, the detection of a deep sulfate reduction zone and the successful enrichment of anaerobic microorganisms was the motivation for isolating sulfate-reducing bacteria (SRB) especially from fluid-influenced sediment layers. Identifying defined physiological adaptations of indigenous microorganisms to environmental conditions can be achieved best when pure cultures are available.

Even though sulfate reduction is supposed to be an important process in deeply buried sediments, only few isolates are available in strain collections. The type strain of Desulfovibrio profundus was isolated from $500 \mathrm{~m}$ depth in sediments of the Japan Sea (Parkes et al., 1995; Bale et al., 1997). Other piezophilic isolates closely related to $D v$. profundus were cultivated from $222 \mathrm{~m}$ deep sediments of the Cascadia margin of the Pacific Ocean (Barnes et al., 1998). However, cultivation-based studies on the marine deep biosphere are still limited to a few sampling sites representing pinpricks in the ocean floor. So far, isolates from the marine subsurface were obtained from sediment samples retrieved from Mediterranean sediments (Süss et al., 2004) and from various sites in the Pacific Ocean: The Sea of Okhotsk, north of Japan (Inagaki et al., 2003), the Nankai Trough south-east of Japan (Mikucki et al., 2003; Toffin et al., 2004a,b, 2005; Kendall et al., 2006), the Equatorial Pacific, and the Peru Margin (D'Hondt et al., 2004; Biddle et al., 2005; Lee et al., 2005; Batzke et al., 2007). Recently, several heterotrophic bacteria and methanogenic Archaea were isolated from up to 106 mbsf deep sediments off Shimokita Peninsula, Japan using a continuous-flow bioreactor (Imachi et al., 2011).

In this study, we extended our previous investigations on IODP Site U1301 to determine the microbial diversity within different sediment layers of the deep subsurface. We hypothesize, that zones with different sulfate concentrations harbor different populations of SRB due to varying substrate availabilities. A cultivation-based approach in combination with molecular screening tools was chosen to isolate and compare SRB from fluid-influenced sediments and near-surface layers. The metabolic properties of the isolates might provide new insights on the impact of crustal fluids on microbial metabolism in the deep-subseafloor biosphere where substrates are recalcitrant but electron acceptors are still available.

\section{MATERIALS AND METHODS SAMPLE MATERIAL}

Sediment samples were recovered from the eastern flank of the Juan de Fuca Ridge by the drill ship "JOIDES Resolution" during IODP Expedition 301 in 2004. Characteristics of IODP Site U1301 were described in the expedition report (Expedition 301 Scientists, 2005). Sediment sampling, contamination tests, and subsampling for further analyses were described in detail by Engelen et al. (2008). All samples proved to be free of contamination as previously described by Lever et al. (2006).

\section{INITIAL ENRICHMENTS OF DEEP-BIOSPHERE BACTERIA}

To elucidate the diversity of cultured bacteria, a total of 736 initial enrichment cultures were set up directly onboard. Sediment slurries from 17 representative depth intervals (Engelen et al., 2008) were prepared immediately after sample recovery with anoxic artificial seawater medium (Süss et al., 2004). MPN series for anoxic and oxic microorganisms from these slurries were performed in 10 -fold steps within 96-deep-well microtiter plates as previously described (Engelen et al., 2008). In addition, liquid dilution series in 20 ml-glass tubes were inoculated, flushed with $\mathrm{N}_{2}$ and sealed with butyl rubber stoppers. Anoxic substrate gradient tubes were prepared with undisturbed $1-\mathrm{cm}^{3}$-sediment subcores from hole U1301C, only by embedding them within agar-solidified artificial seawater media (Köpke et al., 2005). In general, a mixture of the following substrates were supplied to stimulate microbial growth: glycerol, glucose, lactate, fumarate, malate, succinate, methanol, ethanol, 1-propanol, 1-butanol, formate, acetate, propionate, butyrate, valerate, caproate, and all the $20 \mathrm{~L}$-amino acids (final concentration of each compound: $0.1 \mathrm{mM}$ ). For a better comparison of all enrichments, incubation was performed at $20^{\circ} \mathrm{C}$.

Anoxic and oxic MPN viable counts were determined after 14 weeks of incubation to quantify the cultured part of the microbial communities within the sampled sediment layers. Procedure and results have already been published by Engelen et al. (2008). For the present cultivation study, all dilution cultures showing growth were transferred into 20 ml-glass tubes containing freshly prepared media and further incubated for at least five months at $20^{\circ} \mathrm{C}$. Since cell densities were generally low, growth was determined several times during incubation by epifluorescence microscopy using Sybr ${ }^{\circledR}$ GreenI as a fluorescent dye. Growth of sulfate reducers was monitored by measuring the formation of sulfide (Cord-Ruwisch, 1985). Gradient cultures were incubated for approximately one year without interruption. Stimulation of growth within the sediment subcore was analyzed by microscopy and molecular methods. Finally, a total of 116 positive cultures were analyzed by means of molecular biological methods as described below to identify the cultivated microorganisms and to select enrichments for further isolation processes.

\section{ISOLATION OF PURE CULTURES}

Pure cultures from SRB and other anaerobes were isolated and maintained in a slightly different artificial seawater media. One liter of this basal medium contained $24.32 \mathrm{~g} \mathrm{NaCl}, 10.0 \mathrm{~g}$ 
$\mathrm{MgCl}_{2} \cdot 6 \mathrm{H}_{2} \mathrm{O}, 1.5 \mathrm{~g} \mathrm{CaCl}_{2} \cdot 2 \mathrm{H}_{2} \mathrm{O}, 4.0 \mathrm{~g} \mathrm{Na}_{2} \mathrm{SO}_{4}, 0.66 \mathrm{~g} \mathrm{KCl}$, and $0.09 \mathrm{~g} \mathrm{KBr}$. Resazurin $(1 \mathrm{mg} / \mathrm{l})$ was added as redox-indicator. The media was autoclaved, cooled under a nitrogen atmosphere, and supplemented with the following sterile solutions: $\mathrm{NH}_{4} \mathrm{Cl}(2 \mathrm{mM})$, $\mathrm{KH}_{2} \mathrm{PO}_{4}(1 \mathrm{mM}), \mathrm{CO}_{2}$-saturated sodium bicarbonate $(30 \mathrm{mM})$, and from sterile stocks: $1 \mathrm{ml} / \mathrm{l}$ of trace element solution SL10 (Widdel and Bak, 1992) $0.2 \mathrm{ml} / \mathrm{l}$ of selenite-tungsten solution (Widdel and Bak, 1992) and $2 \mathrm{ml} / \mathrm{l}$ of a solution of 10 vitamins (Balch et al., 1979). The anoxic medium was reduced by addition of $\mathrm{Na}_{2} \mathrm{~S}$ (final concentration: $\sim 1 \mathrm{mM}$ ) and few crystals of sodium dithionite. The $\mathrm{pH}$ was adjusted to 7.2-7.5 with $4 \mathrm{M} \mathrm{NaOH}$. To increase cell density of all subcultures, a 10 -fold higher concentrated substrate mix was provided (i.e., final concentration of each compound: $1 \mathrm{mM}$ ).

Repeated application of the deep-agar dilution method (Widdel and Bak, 1992) or dilution-to-extinction was performed to isolate deep-biosphere bacteria from liquid enrichments. Sediment subcores from gradient cultures were homogenized and slurried with $4 \mathrm{ml}$ anoxic artificial seawater to further establish subcultures as gradient dilution series (up to $10^{-6}$ ). Aerobic microorganisms were subcultured for isolation by the liquid dilution-to-extinction method with subsequent purification on agar plates using a HEPES/bicarbonate-buffered oxic seawater medium. The purity of all isolates was checked by microscopy and molecular analysis as described below. Furthermore, the cultures were transferred to a complex HEPES-buffered oxic seawater medium containing yeast extract $(0.03 \mathrm{~g} / \mathrm{l})$, glucose $(1 \mathrm{mM})$, lactate $(5 \mathrm{mM})$, and peptone $(0.06 \mathrm{~g} / \mathrm{l})$ as substrates to check for contamination.

\section{MOLECULAR SCREENING OF ENRICHMENT CULTURES}

The above described enrichment and isolation procedure was monitored and directed by molecular screening to identify unique phylotypes. Positive dilutions or growing colonies were analyzed by using polymerase chain reaction (PCR) of $16 \mathrm{~S}$ rRNA gene-fragments, denaturing gradient gel electrophoresis (DGGE), and subsequent sequencing of re-amplified DGGE bands. DNA from liquid cultures was extracted using a protocol combining bead-beating with phenol/chloroform/isoamyl alcohol treatment and isopropanol/sodium acetate precipitation (Stevens et al., 2005). Nucleic acid extraction from substrate gradient cultures was performed by using the UltraClean ${ }^{\mathrm{TM}}$ Soil DNA Isolation Kit (MoBio Laboratories, Inc., Carlsbad, CA, USA) according to the manufacturers' instructions.

Polymerase chain reaction-amplification of bacterial 16S rRNA genes was conducted in 50- $\mu$ l volumes containing the following components: 1-2 1 l of DNA-template, $10 \mathrm{pmol}$ of each primer, $0.2 \mathrm{mM}$ of each dNTP, $0.5-2 \mu \mathrm{l}$ of bovine serum albumin (BSA, $10 \mathrm{mg} / \mathrm{ml}), 5 \mu \mathrm{l}$ of $10 \times$-ThermoPol reaction buffer and $1 \mathrm{U} / \mu \mathrm{l}$ of Taq Polymerase (New England Biolabs, Inc., Ipswich, MA, USA) and nuclease-free water. For DGGE analysis, the almost complete 16S rRNA genes were amplified with the primer set 8f/1492r (Overmann and Tuschak, 1997). The samples were incubated in a thermal cycler (Mastercycler, Eppendorf, Hamburg, Germany) under the following conditions: initial denaturation at $95^{\circ} \mathrm{C}$ for $5 \mathrm{~min}, 28$ cycles of amplification by denaturation at $95^{\circ} \mathrm{C}$ for $30 \mathrm{~s}$, annealing at $40^{\circ} \mathrm{C}$ for $60 \mathrm{~s}$, and elongation at $72^{\circ} \mathrm{C}$ for $3 \mathrm{~min}$. Terminal elongation was performed at $72^{\circ} \mathrm{C}$ for $10 \mathrm{~min}$. The resulting amplicons were used as templates for a nested PCR. Shorter 16S
rRNA gene-fragments were amplified (Wilms et al., 2006a) using the universal bacterial primer set GC-341f and 907r (Overmann and Tuschak, 1997). All PCR products were always visualized by agarose-gel electrophoresis (Wilms et al., 2006a). DGGE was performed with a gradient from 40 to $70 \%$ (Süss et al., 2004). PCR products were mixed with loading buffer before loading onto the gel (Wilms et al., 2006a).

\section{SEQUENCING OF DGGE BANDS AND PURE CULTURES}

For sequence analysis of DGGE bands, distinctive bands were excised, eluted in $50 \mu \mathrm{l}$ nuclease-free water, re-amplified in a $25-\mu \mathrm{l}$ PCR (primers 341f/907r, Wilms et al., 2006b), and purified (Wilms et al., 2006a) using the QIAquick PCR purification Kit (Qiagen GmbH, Hilden, Germany) or the PCR-Purifying-Kit (SeqLab, Göttingen, Germany) and sequenced with a IRDyeTM800 labeled 907r-primer (Süss et al., 2004). For phylogenetic identification of pure cultures, genomic DNA was extracted from the isolated strains using a freeze and thaw procedure. From picked colonies or $2 \mathrm{ml}$ of liquid cultures, $1 \mu \mathrm{l}$ of a cell pellet was resuspended with $100 \mu \mathrm{l}$ of filter-sterilized Tris-buffer $(50 \mathrm{mM}, \mathrm{pH} 7.4)$. The suspension was frozen at $-80^{\circ} \mathrm{C}$ for $3 \mathrm{~min}$ and heated at $85^{\circ} \mathrm{C}$ for $3 \mathrm{~min}$. This procedure was repeated five times, and $2 \mu \mathrm{l}$ of the final extract were added to $48 \mu \mathrm{l}$ of PCR mixture. Partial or nearly full-length bacterial 16S rRNA gene sequences were amplified using the bacteria-specific primer set 341f/907r and $8 \mathrm{f} / 1492 \mathrm{r}$, respectively, and sequenced as described above. In case of sulfate-reducing strains, DNA was sequenced in both directions using the respective PCR primers and the service of GATC Biotech AG (Konstanz, Germany). Consensus sequences were constructed after alignment by using the BioEdit software tool version 7.0.9 ${ }^{1}$. All 16S rRNA gene sequences obtained in this study were compared for their affiliation to the closest relatives using the BLASTN program 2.2.26+ (Altschul et al., 1990; Morgulis et al., $2008)^{2}$. The partial 16S rRNA gene sequences of all 40 isolates are deposited in GenBank database under the accession numbers JQ411257-JQ411296.

\section{PHYSIOLOGICAL CHARACTERIZATION OF SULFATE-REDUCING ISOLATES}

Physiological tests were generally performed in sealed glass tubes containing $10 \mathrm{ml}$ of artificial seawater medium. Sulfidogenic growth was tested with 18 different substrates at final concentrations between 1 and $5 \mathrm{mM}$ in the presence of sulfate. Fermentative growth with betaine, ethanol, malate, or pyruvate $(2-5 \mathrm{mM}$, each) was tested in medium without additional electron acceptors. The cultures were incubated for at least 4 weeks at $20^{\circ} \mathrm{C}$ in the dark. Chemolithotrophic growth with $\mathrm{H}_{2}$ as electron donor was tested with a headspace (2/3 of the culture volume) filled with a mixture of $\mathrm{H}_{2} / \mathrm{CO}_{2}(80 / 20 \mathrm{v} / \mathrm{v}, 1 \mathrm{kPa})$. Those cultures were incubated horizontally at $20^{\circ} \mathrm{C}$. Growth was checked by visual inspection of turbidity, by phase contrast microscopy, and by sulfide formation (Cord-Ruwisch, 1985). Substrate utilization was defined to be positive after the third successful transfer into fresh media.

\footnotetext{
${ }^{1}$ http://www.mbio.ncsu.edu/BioEdit/bioedit.html

${ }^{2}$ http://blast.ncbi.nlm.nih.gov/Blast.cgi
} 
The capability of anaerobic respiration was tested in sulfate-free medium with ethanol or lactate $(5 \mathrm{mM}$, each) as electron donor in combination with six different electron acceptors. Reduction of $\mathrm{Fe}$ (III) was indicated by the formation of black precipitates under the expense of the reddish ferric hydroxide. Mn(IV) utilization was shown by the disappearance of brown manganese carbonates and the occurrence of white precipitates. The production of sulfide as a result of the reduction of thiosulfate or sulfite was measured at $480 \mathrm{~nm}$ using a Shimadzu UV-1202 photometer (Cord-Ruwisch, 1985). In addition, cultures were checked microscopically for the presence of bacterial cells.

Growth experiments for autotrophic growth were performed at $35^{\circ} \mathrm{C}$, the optimum temperature for growth of our test strain P23. Growth rates were calculated from linear regression of produced sulfide (Cord-Ruwisch, 1985) and formed cell protein (Bradford, 1976) as function of time.

The temperature range for growth of SRB was tested from 4 to $55^{\circ} \mathrm{C}$ with lactate $(10 \mathrm{mM})$ as electron donor. Growth was followed at $\mathrm{OD}_{436}$ via sulfide production and by photometrical determination of protein concentrations (Bradford, 1976).

For phase contrast microscopy, agarose-coated slides were used. To prepare those, slides were thoroughly cleaned and preheated by infrared light in order to get a smooth agarose film. Then, $1 \mathrm{ml}$ of the hot agarose solution $(2 \% \mathrm{w} / \mathrm{v})$ was dispensed on the warm slides. Before usage, the agarose slides were air dried. Upon placing a drop of a bacterial culture to a coated slide, the liquid diffuses into the dry agarose, while the cells are gently squeezed under the cover slip and get fixed in the same plane. Cell dimensions were determined using a Leitz DMRB microscope (Wetzlar, Germany).

Transmission-electron microscopy was performed as follows: a 400-mesh Formvar copper grid (Plano) was placed on a drop of cell suspension for $10 \mathrm{~min}$. Cells adsorbed to the grid were stained with $0.5 \%$ aqueous uranyl acetate for $1 \mathrm{~min}$, washed twice in a drop of water for a few seconds and examined with a transmissionelectron microscope (EM 902A, Zeiss). A Proscan High Speed SSCCD camera system with iTEMfive software was used for images acquisition.

\section{RESULTS \\ GEOCHEMICAL PROFILES DIVIDE THE SEDIMENT COLUMN INTO THREE DISTINCTIVE ZONES}

The geomorphological structure of the eastern flank of the Juan de Fuca Ridge leads to a hydrological situation where sulfatecontaining fluids from the oceanic crust diffuse $\sim 140 \mathrm{~m}$ into overlying sediment layers. The effect of this heat-driven fluid circulation was reflected by the temperature gradient within the sediments of $2^{\circ} \mathrm{C}$ at the seafloor to approximately $62^{\circ} \mathrm{C}$ above the basement (Expedition 301 Scientists, 2005). Using the porewater profile of sulfate, the sediment column can be separated into three zones (Figure 1). The upper sulfate-containing zone was formed by bottom-seawater diffusion showing decreasing concentrations from $27 \mathrm{mM}$ at the top to $3 \mathrm{mM}$ in $35 \mathrm{mbsf}$. Below, a sulfatedepleted zone was located between 47 and $121 \mathrm{mbsf}(<1 \mathrm{mM})$. The lower sulfate-containing zone was characterized by increasing sulfate concentrations from 2 to $16 \mathrm{mM}$ toward the basement at $\sim 265$ mbsf due to sulfate diffusion from crustal fluid flow into the overlying sediments.

\section{SHIFTS IN MICROBIAL DIVERSITY BETWEEN THE INITIAL ENRICHMENT CULTURES FROM THE DIFFERENT ZONES}

Anoxic and oxic MPN series, liquid dilution series in tubes and the substrate gradient technique were used to enrich and further isolate deep-biosphere bacteria. The cultivation progress was monitored by microscopy and PCR-DGGE. Unique DGGE bands were subsequently sequenced to identify the community composition within the enrichments. A total of 135 partial $16 \mathrm{~S}$ rRNA gene sequences were obtained after DGGE analysis of growing cultures. The technique was not only chosen to prevent multiple isolation of one strain and to check the purity of cultures, but also to identify community members that could not be isolated. This molecular-directed cultivation indicated the presence of diverse viable microbial populations within the different zones of the investigated sediment column.

The phylogenetic screening of the initial enrichments identified different bacterial populations among the growing cultures obtained from the three sediment zones (Figure 1). A typical decrease in cultivation success with respect to the conditions set in our growth media was observed for the two upper zones, which correlates with the general depletion of electron donors and acceptors. Within the top $30 \mathrm{~m}$ of the sediment column, 35 different operational taxonomic units (OTUs, defined at 97\% sequence similarity) were detected via PCR-DGGE in enrichments from the respective sediment layers. From the sulfate-depleted zone, 21 OTUs were retrieved. For samples from the deep, fluid-influenced sediment zone, the cultivation success increased again with 48 identified OTUs.

In general, the number of OTUs belonging to the Firmicutes decreased with sediment depth from $60 \%$ in enrichments from the upper sulfate-containing zone to $21 \%$ in the lower sulfate zone. In addition, Gammaproteobacteria accounted for $40 \%$ of all OTUs retrieved from enrichments of the lower sulfate zone. Bacteria belonging to the phylum Acidobacteria, Bacteroidetes, and the classes Beta- and Epsilonproteobacteria were enriched as identified by molecular methods but could not be isolated or were lost during purification procedures. The majority of the enriched but not isolated organisms were phylogenetically affiliated to uncultured bacteria from different terrestrial and marine environments (data not shown in detail).

\section{DIVERSITY OF ISOLATED PURE CULTURES}

From the 116 initial enrichments that were tested positively for growth, 40 strains could be isolated (14 from the upper sulfatecontaining zone, 8 from the sulfate-depleted zone, and 18 from the lower sulfate-containing zone). Based on 16S rRNA gene sequences, the 40 pure cultures could be affiliated to the phyla Actinobacteria, Firmicutes, and Tenericutes or the classes Alphaproteobacteria, Gammaproteobacteria, Deltaproteobacteria (Table 1). The majority of isolates (32 of 40) were obtained from liquid dilution series that were initially inoculated with hundred to million fold diluted sediment $\left(10^{-2}\right.$ to $\left.10^{-6}\right)$, indicating a significant number of cells in situ. Nearly all isolates were closely related to cultivated species from sediments or soils, fluids, or other aquatic environments. Among them, 13 were strict anaerobes. With exception of the sporeforming Firmicutes all other pure cultures including those obtained from oxic media were 


\section{Pore water sulfate (mM)}

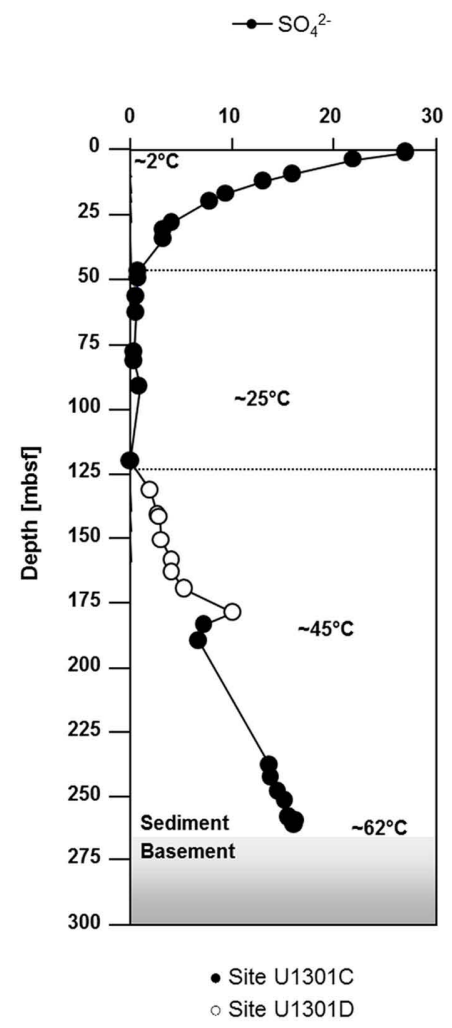

Phylogenetic affiliation of enriched community members

Number and affiliaton of OTUs Detected and $\left({ }^{*}\right)$ isolated SRB

Upper sulfate-containing zone 1.3 to $35 \mathrm{mbsf}$

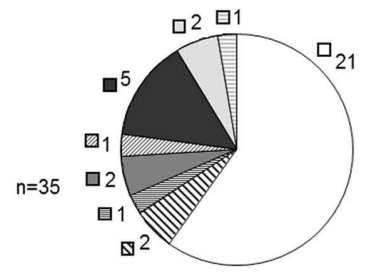

\section{Firmicutes}

Desulfosporosinus sp. 44a-T3a Desulfosporosinus lacus ${ }^{\top}\left({ }^{*}\right)$ Desulfotomaculum sp. $175\left(^{*}\right)$ Deltaproteobacteria Desulfovibrio aespoeensis ${ }^{\top}\left(^{*}\right)$

Sulfate-depleted zone 52 to $122 \mathrm{mbsf}$

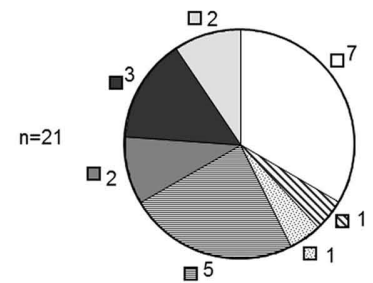

\section{Deltaproteobacteria}

Desulfovibrio aespoeensis Aspo 3 Desulfovibrio vulgaris strain VNs5i

Lower sulfate-containing zone 132 to 261 mbsf

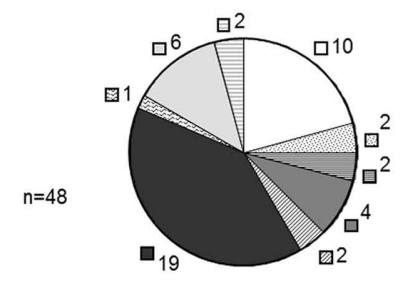

Deltaproteobacteria Desulfovibrio aespoeensis ${ }^{\top}$ Desulfovibrio indonesiensis ${ }^{\top}\left({ }^{*}\right)$ Desulfovibrio vulgaris subsp. Desulfotignum balticum $\left.{ }^{\top}{ }^{*}\right)$

Firmicutes Actinobacteria Alphaproteobacteria Deltaproteobacteria $\square$ Epsilonproteobacteria $\square$ Gammaproteobacteria Acidobacteria $\square$ Bacteroidetes $\mathrm{O}$ Tenericutes
FIGURE 1 | Zonation of the 265-m-long sediment column of the eastern flank of the Juan de Fuca Ridge, Northeast Pacific (IODP Site U1301), and phylogenetic affiliation of enriched and isolated marine subsurface bacteria with special emphasis on sulfate-reducing bacteria. Operational taxonomic units (OTUs) detected via PCR-DGGE are defined at $97 \%$ sequence similarity. considered to be facultatively anaerobic, since they originated from anoxic sediment horizons. While some isolates seem to be ubiquitous within the sediment column [e.g., Shewanella frigidimarina, 98-99\% sequence similarity or Bacillus spp. (96-100\%)], others were retrieved from single sediment layers, only (e.g., Anaerovirgula multivorans or Marinobacter flavimaris, both $99 \%$ sequence similarity).

\section{SULFATE-REDUCING BACTERIA WERE ISOLATED FROM BOTH SULFATE-CONTAINING ZONES}

The sulfate reducers isolated from the upper $10 \mathrm{~m}$ predominantly belonged to the Firmicutes (Figures 1 and 2; Table 1). Three strains were identified as members of the genera Desulfotomaculum and Desulfosporosinus. The latter shared $97 \%$ sequence similarity with its closest described relative Desulfosporosinus lacus, firstly isolated from freshwater lake sediments (Ramamoorthy et al., 2006). The Desulfotomaculum strains were phylogenetically related to isolates originally obtained from a terrestric aquifer system (Detmers et al., 2001). Another isolate from a near-surface layer (strain P20) was closely affiliated to Desulfovibrio aespoeensis. This Deltaproteobacterium was also enriched in co-culture with strains related to Desulfovibrio indonesiensis (culture P34 and P19) from 240 and 260 mbsf, respectively, as identified by DGGE and subsequent sequencing of the bands. Two sequences affiliated to sulfate reducers were also detected in enrichment cultures from sediments of the sulfate-depleted zone (Figure 1). However, no isolates could be retrieved. SRB isolated from the deepest sediments above the basement solely belonged to the Deltaproteobacteria, namely Desulfotignum balticum (strain P18; 260 mbsf) and Dv. indonesiensis (strains P12, P19-1, P23, P33, and P34). The latter phylotype was highly abundant in the lower sulfate-containing zone as it was frequently retrieved from different fluid-influenced layers (240, 252, 260 mbsf). Furthermore, strains P18, P23, and P34 were isolated from million fold diluted MPN-cultures, allowing the assumption, that they must be present in higher numbers within the respective sediment layer, where they probably play an active role.

\section{MORPHOLOGICAL AND PHYSIOLOGICAL CHARACTERISTICS OF THREE REPRESENTATIVE SULFATE-REDUCING ISOLATES}

Strains affiliated to $D v$. aespoeensis (strain P20), Dv. indonesiensis (strain P23), and Desulfotignum balticum (strain P18) were morphologically and physiologically investigated in more detail (Figure 2; Table 2). Strain P20 was used for further analysis since it was the only available pure culture related to $D v$. aespoeensis that was obtained in this study. Other relatives of this species were 
Table 1 | Origin and phylogenetic affiliation of isolated strains from IODP Site U1301, a 265-m-long sediment column of the eastern flank of the Juan de Fuca Ridge, Northeast Pacific.

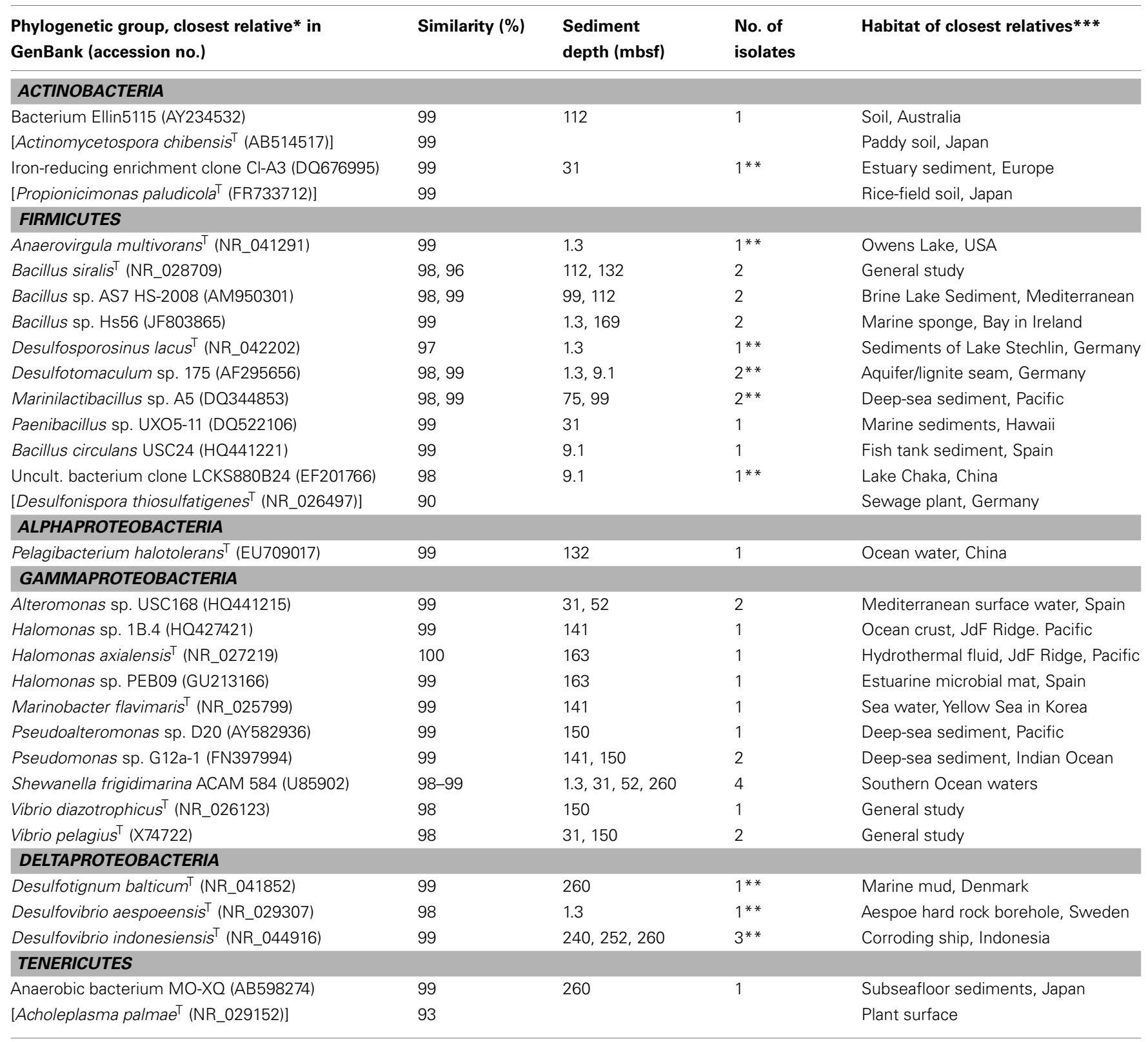

*In case of environmental clones the next cultivated organism is indicated in square brackets.

** Strictly anaerobic isolates.

***Based upon the results of the megaBLAST search (NCBI).

enriched from near-basement layers, but only in co-culture with strains affiliated to $D v$. indonesiensis. Various efforts to separate the two species failed. Strain P23, obtained from the deepest sediment layer $(260 \mathrm{mbsf})$, was chosen as a representative for strains related to $D v$. indonesiensis, since the other closely related isolates showed nearly identical characteristics under the growth conditions tested.

For all investigated strains, colonies formed in deep-agar dilution series exhibited yellowish to brownish colors. The
Desulfovibrio affiliated strains showed curved, motile cells (Figures 2A,C) with single polar flagella as identified by electron microscopy of negatively stained cells (Figures $2 \mathrm{~B}, \mathbf{D}$ ). The relative of the non-motile Desulfotignum balticum formed $\sim 2-3 \mu \mathrm{m}$ short thick rods with rounded ends (Figures $2 \mathrm{E}, \mathrm{F}$ ).

Desulfovibrio aespoeensis strain P20 grew within a temperature range of $20-35^{\circ} \mathrm{C}$ with an optimum at $25^{\circ} \mathrm{C}$. Desulfotignum strain P18 and Dv. indonesiensis strain P23 instead exhibited growth within a broad temperature range from 4 to $48^{\circ} \mathrm{C}$ and 10 to $48^{\circ} \mathrm{C}$, 


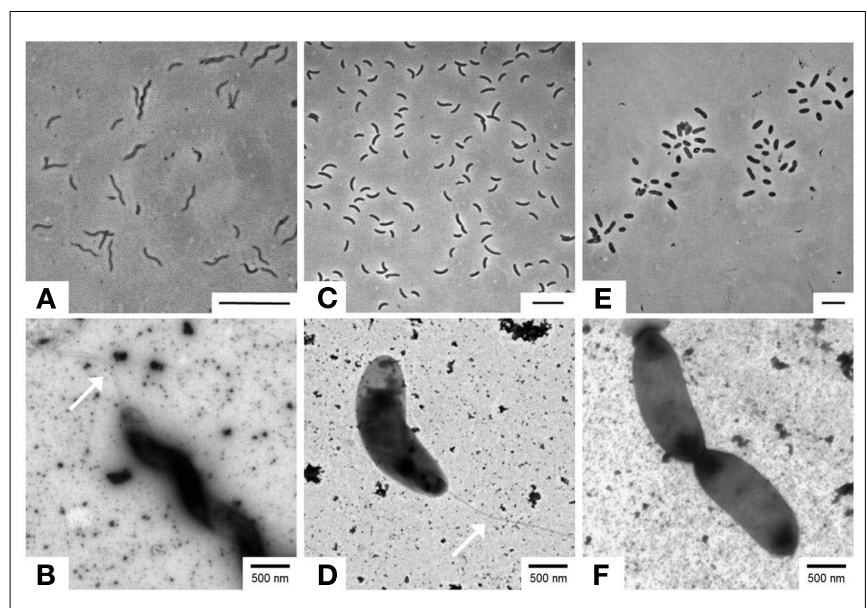

FIGURE 2 | Microscopic images from three sulfate-reducing isolates obtained from sediments of IODP Site U1301. (A,B) Desulfovibrio aespoeensis strain P20 (1.3 mbsf); (C,D) Desulfovibrio indonesiensis strain P23 (260.4 mbsf); (E,F) Desulfotignum balticum strain P18 (260.4 mbsf). Upper images: phase contrast (bar $=5 \mu \mathrm{m}$ ); lower images:

transmission-electron microscopy, TEM (bar $=500 \mathrm{~nm})$. Arrows in (B,D) indicate flagella.

respectively, with the optimal growth temperature lying between 25 and $35^{\circ} \mathrm{C}$.

All strains were capable of using sulfite or thiosulfate as alternative electron acceptor other than sulfate. Slow growth by iron or manganese reduction on lactate was observed for Desulfotignum balticum strain P18 and Dv. indonesiensis strain P23. Growth was not as fast as with sulfate as electron acceptor and high cell densities were not achieved. However, growth on metal oxides occurred even after the third transfer. None of the strains used nitrate as electron acceptor for anaerobic respiration.

Of all substrates provided, Dv. aespoeensis strain P20 only utilized lactate and formate for growth in the presence of sulfate. In contrast, the type strain of $D v$. aespoeensis only grew on lactate as sole substrate (Motamedi and Pedersen, 1998). The two other strains tested (P18 and P23) showed a slightly broader substrate spectrum. Strain P23, for instance, grew on different $n$-alcohols (C2-C4), formate, fumarate, lactate, and pyruvate. Only Desulfotignum strain P18 grew on acetate, benzoate, betaine, butyrate, and succinate, whereas fast growth and high cell densities were achieved with betaine, which was also fermented. Fermentative growth with pyruvate occurred in Desulfovibrio strains, only. All strains used hydrogen as electron donor. Desulfotignum balticum strain P18 grew autotrophically but only in the presence of vitamins. This was already known for the type strain of Desulfotignum balticum, which was described to grow on $\mathrm{H}_{2}$ and $\mathrm{CO}_{2}$ (Kuever et al., 2001). Surprisingly, autotrophic growth for Dv. indonesiensis strain P23 was observed in media that did not contain any organic additives such as vitamins, resazurin, or yeast extract and after at least 10 transfers to eliminate carbon sources from initial cultures (Figure 3). Growth rates (based on protein production) for strain P23 were $0.12 \mathrm{~d}^{-1}$ under autotrophic conditions, and approximately three times higher $\left(0.30 \mathrm{~d}^{-1}\right)$ when $1 \mathrm{mM}$ of acetate was added.

\section{DISCUSSION \\ ORGANIC MATTER AND SULFATE AVAILABILITY GENERATE THE THREE DIFFERENT ZONES OF THE SEDIMENT COLUMN}

The stratification of the different sediment compartments has an imprint on the life conditions. In both, the seawater- and fluid-influenced layers, the availability of electron acceptors stimulates microbial growth and activity of indigenous microorganisms (Engelen et al., 2008). In terms of electron donors, bacteria that thrive in the upper $30 \mathrm{~m}$ of the sediments are supported by burial of relatively young organic carbon (Fisher et al., 2003; Johnson et al., 2006). Therefore, they are used to a higher supply of electron donors and adapt much better to the given cultivation conditions. In deeper sediment horizons, indigenous bacteria have to survive long-term burial by adapting to a minimum supply of substrates and electron acceptors. Their limited availability strongly influences the metabolic activities in the deep marine subsurface. Indeed, based on geochemical porewater profiles, it has been concluded that the metabolic activities of subseafloor prokaryotes are very low (D'Hondt et al., 2002, 2004). They probably have developed different life strategies such as slow growth or survival as spores. The latter were presumably stimulated to germinate during our cultivation experiments since a major part of 16S rRNA gene sequences detected in all enrichment cultures affiliated to sporeforming Firmicutes (Figure 1). However, the decreasing number of Firmicutes with depth indicates that not all of them survive the long-term burial as spores as they might have germinated stochastically over geological time scales (Epstein, 2009).

Other subsurface organisms that are adapted to low organic carbon concentrations might not be able to grow under the given laboratory conditions. Even though the composition of our culture media was designed to provide organic substrates in submillimolar concentrations, a substrate shock (Straskrabová, 1983) might not have been circumvented. For instance, we were not able to grow any Archaea (data not shown) even though they are proposed to represent a substantial part of the deep biosphere as indicated by intact-lipid analysis (Lipp et al., 2008).

The supply of electron acceptors into the sediment column by crustal fluid diffusion dramatically changes the situation for microbial life within these deeply buried layers. The large numbers of non-sporeforming Gammaproteobacteria that were enriched from near-basement layers indicate the presence of viable cells. Many Gammaproteobacteria are adapted to elevated substrate concentrations (Lauro et al., 2009) and are therefore readily cultivated using our media. Some of them might even be typical for oceanic ridge systems. Halomonas and Marinobacter species were found to be present in hydrothermal fluids collected at the Juan de Fuca Ridge (Kaye et al., 2011). They were enriched during in situ colonization experiments on basaltic crust (Smith et al., 2011) and have also been detected in basaltic seafloor lavas and overlying seawater at the East Pacific Rise (Santelli et al., 2008).

\section{THE UPPER AND LOWER SULFATE-CONTAINING ZONES HARBOR DIFFERENT SULFATE-REDUCING BACTERIA}

The majority of sequences obtained from upper sediment horizons that were affiliated to SRB have Desulfosporosinus and Desulfotomaculum species as closest relatives, both sporeforming Firmicutes. However, it is unclear if they contribute to the high sulfate 
Table 2 | Comparison of characteristics of sulfate-reducing isolates from IODP Site U1301: temperature range of growth, morphology, substrate utilization, and alternative electron acceptors.

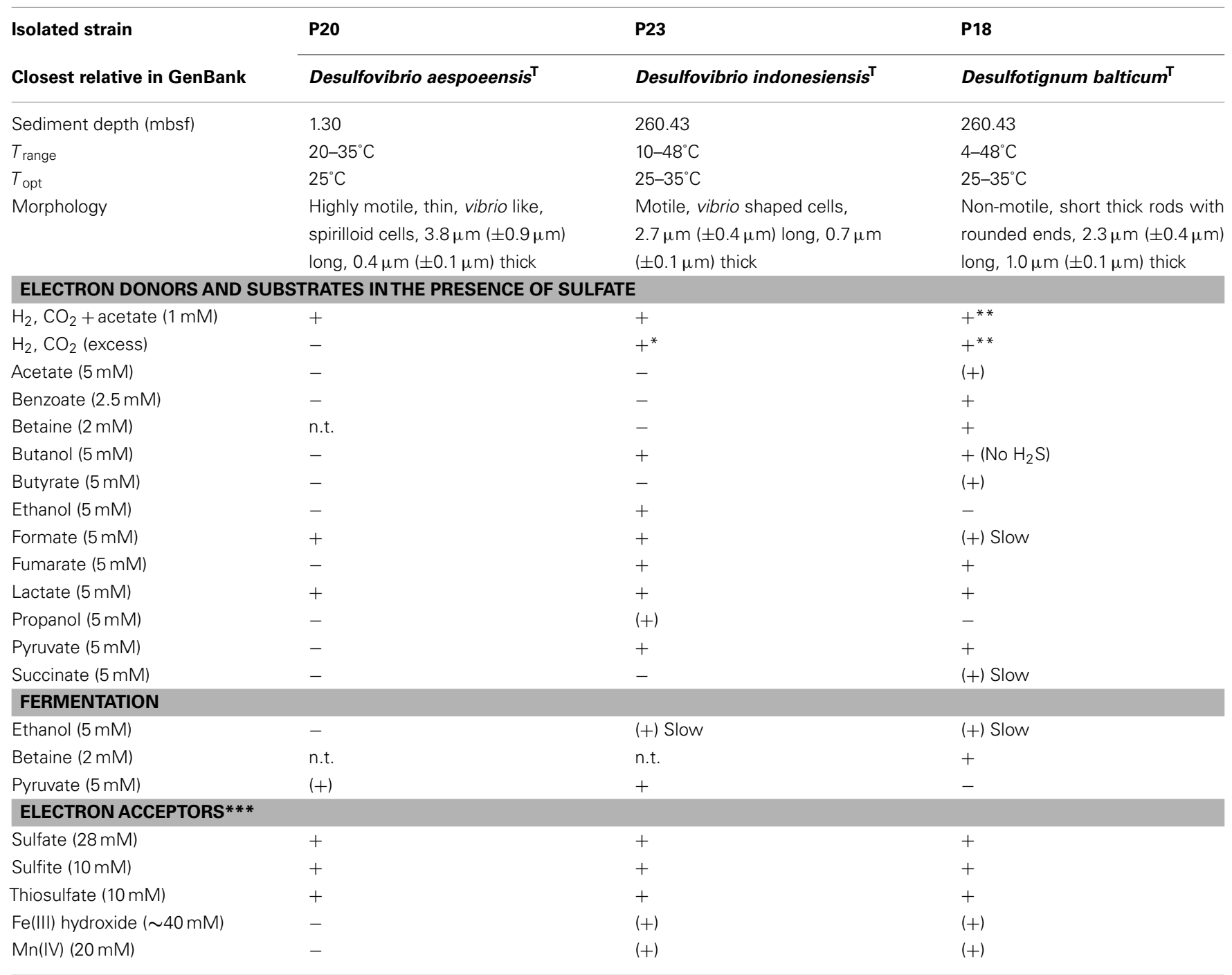

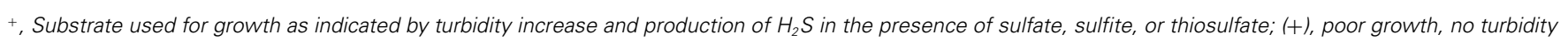
increase, but significant production of $\mathrm{H}_{2} \mathrm{~S}$, in the presence of sulfate; -, no growth; n.t., not tested.

${ }^{*}$ Even in absence of vitamins and resazurin as redox-indicator; ${ }^{*}$ In presence of vitamins only.

***In presence of $\mathrm{N}_{2} / \mathrm{CO}_{2}$ or $\mathrm{H}_{2} / \mathrm{CO}_{2}$ and lactate or ethanol.

The culture medium contained $28 \mathrm{mM}$ sulfate as electron acceptor. For fermentation tests and utilization of alternative electron acceptors, a sulfate-free culture medium was used. No strain grew on amino acid mix (1 mM), glucose ( $5 \mathrm{mM})$, malate ( $5 \mathrm{mM})$, methanol ( $5 \mathrm{mM})$, propionate $(2 \mathrm{mM})$, or yeast extract (0.005\% v/ $)$. None of the strains fermented malate $(5 \mathrm{mM})$ or used nitrate $(10 \mathrm{mM})$ as alternative electron acceptor.

reduction rates of up to $8 \mathrm{nmol} \mathrm{cm}^{-3} \mathrm{~d}^{-1}$ determined for the upper sulfate-containing zone of IODP Site U1301 (Engelen et al., 2008). This would only be the case if these SRB are present as viable cells. It cannot be specified if they are metabolically active or if they only survive as spores within these layers.

In contrast, fluid-influenced sediments exclusively harbor sulfate reducers that are members of the Deltaproteobacteria, which are not known to form any resting stages. These viable populations contribute to sulfate reduction rates of up to $3 \mathrm{pmol} \mathrm{cm}^{-3} \mathrm{~d}^{-1}$ within the lower sulfate reduction zone (Engelen et al., 2008). Due to their high abundance, this activity might derive from sulfate reducers affiliated to $D v$. indonesiensis. This is quite surprising since the in situ temperature is around $60^{\circ} \mathrm{C}$ and most Desulfovibrio species are not active above $40^{\circ} \mathrm{C}$ (Widdel and Bak, 1992). However, a broad temperature range of growth was not only found for our isolates, but also for the Japan Sea isolates of $D v$. profundus (Bale et al., 1997) and might represent an adaptation to the conditions in the deep biosphere.

Thus, one reason for the divergence in the SRB communities detected in both sulfate-containing zones might be the different temperature and pressure regimes present at the top and bottom of the sediment column. Surprisingly, the isolates from the 


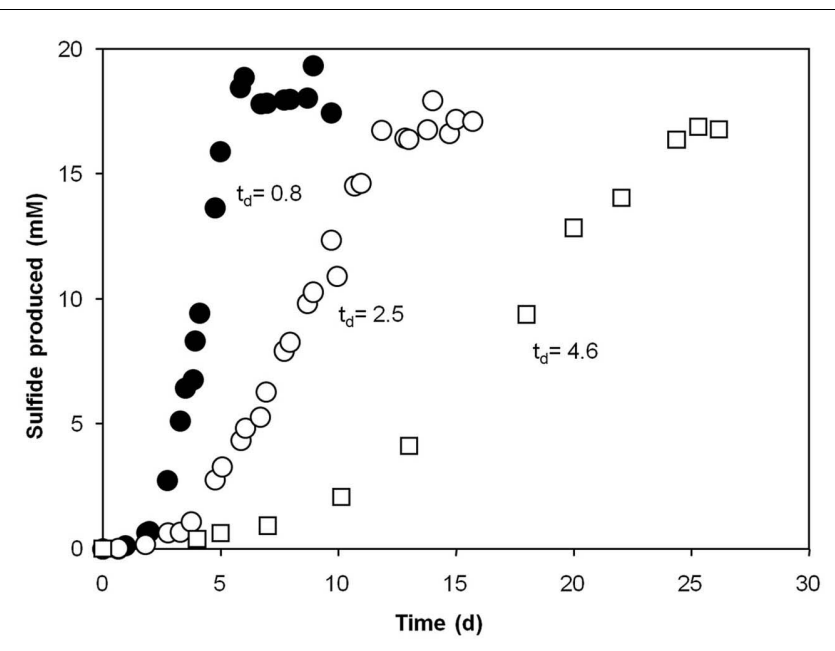

FIGURE 3 | Comparison of heterotrophic and autotrophic growth of Desulfovibrio indonesiensis strain $\mathrm{P} 23$ at $35^{\circ} \mathrm{C}(\mathrm{O})$ under autotrophic conditions using hydrogen, $\mathrm{CO}_{2}$ and sulfate $(28 \mathrm{mM}) ;(O)$ after addition of $1 \mathrm{mM}$ acetate, both in the presence of resazurin and vitamins; $(\square)$ under autotrophic conditions in media without vitamins and resazurin. Doubling times $\left(t_{\mathrm{d}}\right)$ in days are indicated.

deepest fluid-influenced layers did not grow at in situ temperatures of approximately $60^{\circ} \mathrm{C}$. This might be due to the chosen initial incubation conditions at $20^{\circ} \mathrm{C}$ and ambient hydrostatic pressure instead of the in situ pressure of $\sim 30 \mathrm{MPa}$. As temperature and pressure counteract on the cell membrane composition (Mangelsdorf et al., 2005), an insufficient combination of both parameters might result in membrane disintegration. This assumption is supported by the fact that no isolates were obtained from enrichment cultures that were incubated under in situ temperatures (data not shown). In future experiments, pressure incubations might help to overcome such problems in cultivation efficiencies.

\section{SULFATE-REDUCING BACTERIA FROM THE LOWER ZONE HAVE RELATIVES IN DEEP TERRESTRIAL AOUIFERS}

Previous microbiological investigations on crustal fluids from the Juan de Fuca Ridge have identified several isolates (Nakagawa et al., 2006) and 16S rRNA clones (Cowen et al., 2003; Huber et al., 2006) that were affiliated to SRB. In general, the overlap between these studies compared with our culture collection from fluid-influenced sediments is quite low. Only relatives of Desulfotomaculum and Desulfonatronovibrio species were detected in two studies on the adjacent ODP Site 1026. One 16S rRNA gene sequence that is affiliated to Desulfobacterium species was found in fluids that discharge at "Baby bare seamount." A possible explanation for this discrepancy might be that most of our isolates represent typical sediment inhabitants, which do not necessarily occur in the upper oceanic crust. However, our Deltaproteobacteria that were isolated from the lower sulfate-containing zone are facing similar physico-chemical conditions in the highly compacted sediments above the basement as in the crustal aquifer.

A close relation of deep marine with terrestrial aquifers is indicated by the cultivation of $D v$. aespoeensis strains from the fluid-influenced layers. Dv. aespoeensis is the most abundant sulfate reducer within formation waters of deep terrestrial boreholes at the Aespoe hard rock laboratory in Sweden (Motamedi and Pedersen, 1998). Those aquifers are also inhabited by complex microbial communities that are comparable to those thriving within the ocean crust (Pedersen, 2000). The energetical constrains are similar and select for, e.g., iron-reducing bacteria, acetogens, methanogens, and sulfate reducers (Pedersen, 1997).

Our most frequently isolated strains from up to $260 \mathrm{~m}$ deep fluid-influenced sediments that are affiliated to $D v$. indonesiensis also have close relatives within the deep terrestrial biosphere. Even though the type strain was originally isolated from a biofilm on a corroded ship off the Indonesian coast (Feio et al., 1998, 2000), relatives were obtained from porewater brines of a deep terrestrial gas-reservoir (Sass and Cypionka, 2004). Furthermore, these organisms are supposedly involved in iron corrosion as determined during a study on hydrogen-consuming microorganisms in oil facilities from Japan (Mori et al., 2010). Biocorrosive capabilities (Feio et al., 1998) of Dv. indonesiensis might be an indication for a crustal origin of this species as this process plays an important role in the weathering of basalts (Edwards et al., 2005). Under anoxic conditions, SRB, and especially Desulfovibrio species are responsible for the corrosion of metal surfaces in consuming cathodic hydrogen (Pankhania, 1988; Dinh et al., 2004). This process might occur in the habitat as well as in our metabolic tests. As all isolates deriving from the fluid-influenced zone were capable of using hydrogen as electron donor, they might even exhibit a chemolithoautotrophic life-mode in situ.

\section{CHEMOLITHOAUTOTROPHY WITHIN THE DEEP BIOSPHERE}

Autotrophic, hydrogen-consuming microorganisms were repeatedly detected in deep continental aquifers and can even outnumber heterotrophs (Stevens and McKinley, 1995). The assumption that autotrophy is also a common metabolic attribute within the crust at IODP Site U1301, is supported by the isolation of a novel member of the genus Archaeoglobus from a fluid-influenced sample of ODP Site 1226 (Steinsbu et al., 2010). Archaeoglobus sulfaticallidus sp. nov., is a thermophilic and facultatively lithoautotrophic sulfate reducer and was isolated from black rust formations on top of a leaking borehole seal.

Although there is no clear evidence available for lithoautotrophy within the subseafloor (Stevens, 1997), there are numerous studies that deal with hydrogen as suitable source for deep subsurface life. In these habitats, hydrogen can originate from many sources (Nealson et al., 2005) such as the fermentation of organic matter or mechanochemical processes due to the tectonic action of the Earth (Parkes et al., 2011), degassing from the Earth's mantle during serpentinization of ultramafic rocks (McCollom and Bach, 2009), or even by radiolysis of water (Blair et al., 2007; D'Hondt et al., 2009). Furthermore, in the presence of sulfate, the oxidation of hydrogen is thermodynamically favored at high temperatures (Orcutt et al., 2010).

Thus, in many deep subsurface habitats, hydrogen might become apparently the biochemically most important electron donor and carbon dioxide is a ubiquitous carbon source. For example, both gases were found in micro-molar concentrations in deep igneous-rock aquifers (Pedersen, 1997) and deep aquifers of the Columbia river basalt which is located close to our investigated 
site (Stevens and McKinley, 1995). For both sites, the authors have proposed a model for a hydrogen-driven biosphere. They assume autotrophic acetogens to form acetate from hydrogen and carbon dioxide. Acetoclastic methanogens can utilize acetate to produce methane or hydrogenotrophic methanogens might directly use hydrogen and $\mathrm{CO}_{2}$. At relatively young ridge-flank systems, hydrogen-utilizing sulfate reducers will outcompete methanogens as sulfate is still available within the fluids.

\section{CONCLUSION}

Even though cultivation might not cover the whole microbial diversity of a given habitat, we were able to isolate and physiologically characterize indigenous microorganisms that are numerically and metabolically important for the marine deep subsurface. Thus, cultivation-based studies offer the opportunity to complement molecular techniques. In our study, the isolation of SRB from deep sediment layers was the precondition to answer questions concerning specific metabolic adaptations to the conditions at the sediment-basement interface.

\section{REFERENCES}

Altschul, S. F., Gish, W., Miller, W., Myers, E. W., and Lipman, D. J. (1990). Basic local alignment search tool. J. Mol. Biol. 215, 403-410.

Balch, W. E., Fox, G. E., Magrum, L. J., Woese, C. R., and Wolfe, R. S. (1979). Methanogens: reevaluation of a unique biological group. Microbiol. Rev. 43, 260-296.

Bale, S. J., Goodman, K., Rochelle, P. A., Marchesi, J. R., Fry, J. C., Weightman, A. J., and Parkes, R. J. (1997). Desulfovibrio profundus sp. nov., a novel barophilic sulfatereducing bacterium from deep sediment layers in the Japan Sea. Int. J. Syst. Bacteriol. 47, 515-521.

Barnes, S. P., Bradbrook, S. D., Cragg, B. A., Marchesi, J. R., Weightman, A. J., Fry, J. C., and Parkes, R. J. (1998). Isolation of sulfate-reducing bacteria from deep sediment layers of the Pacific Ocean. Geomicrobiol. J. 15, 67-83.

Batzke, A., Engelen, B., Sass, H., and Cypionka, H. (2007). Phylogenetic and physiological diversity of cultured deep-biosphere bacteria from equatorial Pacific Ocean and Peru Margin sediments. Geomicrobiol. J. 24, 261-273.

Biddle, J. F., House, C. H., and Brenchley, J. E. (2005). "Enrichment and cultivation of microorganisms from sediment from the slope of the Peru Trench (ODP Site 1230)," in Proceedings of Ocean Drilling Program, Scientific Results, 201, eds B. B. Jørgensen, S. L. D'Hondt, and D. J. Miller (College Station, TX: Ocean Drilling Program), Available at: http://wwwodp.tamu.edu/publications/201_SR /107/107.htm
Blair, C., D'Hondt, S., Spivack, A., and Kingsley, R. (2007). Radiolytic hydrogen and microbial respiration in subsurface sediments. Astrobiology 7, 951-970.

Bradford, M. M. (1976). A rapid and sensitive method for the quantitation of microgram quantities of protein utilizing the principle of protein-dye binding. Anal. Biochem. 72, 248-254.

Butterfield, D. A., Jonasson, I. R., Massoth, G. J., Feely, R. A., Roe, K. K., Embley, R. E., Holden, J. F., McDuff, R. E., Lilley, M. D., and Delaney, J. R. (1997). Seafloor eruptions and evolution of hydrothermal fluid chemistry. Philos. Trans. R. Soc. Lond. A 355, 369-386.

Cord-Ruwisch, R. (1985). A quick method for the determination of dissolved and precipitated sulfides in cultures of sulfate-reducing bacteria. J. Microbiol. Methods 4, 33-36.

Cowen, J. P. (2004). The microbial biosphere of sediment-buried oceanic basement. Res. Microbiol. 155, 497-506.

Cowen, J. P., Giovannoni, S. J., Kenig, F., Johnson, H. P., Butterfield, D., Rappe, M. S., Hutnak, M., and Lam, P. (2003). Fluids from aging ocean crust that support microbial life. Science 299, 120-123.

DeLong, E. F. (2004). Microbial life breathes deep. Science 306, 2198-2200.

Detmers, J., Schulte, U., Strauss, H., and Kuever, J. (2001). Sulfate reduction at a lignite seam: microbial abundance and activity. Microb. Ecol. 42, 238-247.

D’Hondt, S., Jørgensen, B. B., Miller, D. J., Batzke, A., Blake, R., Cragg, B. A.,

The isolation of facultatively autotrophic sulfate reducers from near-basement layers strongly suggests that these organisms survive due to their capability of consuming hydrogen after organic compounds have been depleted or become too recalcitrant for microbial degradation. The continuous supply of sulfate from the aquifer below supports their viability within their respective sediment layers even after the separation from organic matter input at the seafloor due to sediment accumulation. When organic substrate availability from the ocean becomes a limiting factor, hydrogen becomes the most important electron donor.

\section{ACKNOWLEDGMENTS}

Katharina Schmidt, Heiner Hartwich, Dewi Nasima, and Martin Mierzejewski assisted in molecular analyses and cultivation studies. Andrea Schlingloff is thanked for her help in DNA sequencing and Erhard Rhiel is acknowledged for preparing TEM photos. This study used samples and data provided by the Integrated Ocean Drilling Program from IODP Exp. 301. The work was financially supported by the German Research Foundation (DFG).

Cypionka, H., Dickens, G. R., Ferdelman, T., Hinrichs, K. U., Holm, N. G., Mitterer, R., Spivack, A., Wang, G. Z., Bekins, B., Engelen, B., Ford, K., Gettemy, G., Rutherford, S. D., Sass, H., Skilbeck, C. G., Aiello, I. W. Guèrin, G., House, C. H., Inagaki, F., Meister, P., Naehr, T., Niitsuma, S., Parkes, R. J., Schippers, A., Smith, D. C., Teske, A., Wiegel, J., Padilla, C. N., and Acosta, J. L. S. (2004). Distributions of microbial activities in deep subseafloor sediments. Science 306, 2216-2221.

D'Hondt, S., Rutherford, S., and Spivack, A. J. (2002). Metabolic activity of subsurface life in deep-sea sediments. Science 295, 2067-2070.

D’Hondt, S., Spivack, A., Pockalny, R., Ferdelman, T., Fischer, J., Kallmeyer, J., Abrams, L., Smith, D., Graham, D., Hasiuk, F., Schrum, H., and Stancin, A. (2009). Subseafloor sedimentary life in the South Pacific Gyre. Proc. Natl. Acad. Sci. U.S.A. 106, 11651-11656.

Dinh, H. T., Kuever, J., Mussmann, M., Hassel, A. W., Stratmann, M., and Widdel, F. (2004). Iron corrosion by novel anaerobic microorganisms. Nature 427, 829-832.

Edwards, K. J., Bach, W., and McCollom, T. M. (2005). Geomicrobiology in oceanography: mineralmicrobe interactions at and below the seafloor. Trends Microbiol. 13, 449-459.

Edwards, K. J., Bach, W., and Rogers, D. R. (2003). Geomicrobiology of the ocean crust: a role for chemoautotrophic Fe-bacteria. Biol. Bull. 204, 180-185.

Ehrhardt, C. J., Haymon, R. M., Lamontagne, M. G., and Holden, P. A (2007). Evidence for hydrothermal
Archaea within the basaltic flanks of the East Pacific Rise. Environ. Microbiol. 9, 900-912.

Engelen, B., Ziegelmüller, K., Wolf, L., Köpke, B., Gittel, A., Cypionka, H., Treude, T., Nakagawa, S., Inagaki, F., Lever, M. A., and Steinsbu, B. O. (2008). Fluids from the oceanic crus support microbial activities within the deep biosphere. Geomicrobiol. J. 25, 56-66.

Epstein, S. S. (2009). Microbial awakenings. Nature 457, 1083.

Expedition 301 Scientists. (2005). "Site U1301," in Proceedings of Integrated Ocean Drilling Program, 301, eds A. T. Fisher, T. Urabe, A Klaus, and Expedition 301 Scientists (College Station, TX: Integrated Ocean Drilling Program Management International, Inc.), doi:10.2204/iodp.proc.301.106.2005

Feio, M. J., Beech, I. B., Carepo, M., Lopes, J. M., Cheung, C. W. S., Franco, R., Guezennec, J., Smith, J. R., Mitchell, J. I., Moura, J. J. G., and Lino, A. R. (1998). Isolation and characterisation of a novel sulphatereducing bacterium of the Desulfovibrio genus. Anaerobe 4, 117-130.

Feio, M. J., Beech, I. B., Carepo, M., Lopes, J. M., Cheung, C. W. S., Franco, R., Guezennec, J., Smith, J. R., Mitchell, J. I., Moura, J. J. G. and Lino, A. R. (2000). "Desulfovibrio indonesiensis corrig. sp. nov.," in validation of publication of new names and new combinations previously effectively published outside the IJSEM. List no. 75. Int. J. Syst. Evol. Microbiol. 50, 1415-1417.

Fisher, A. T., Davis, E. E., Hutnak, M., Spiess, V., Zühlsdorff, L., Cherkaoui, A., Christiansen, L., Edwards, K., Macdonald, R., Villinger, H., Mottl, 
M. J., Wheat, C. G., and Becker, K. (2003). Hydrothermal recharge and discharge across $50 \mathrm{~km}$ guided by seamounts on a young ridge flank. Nature 421, 618-621.

Furnes, H., and Staudigel, H. (1999). Biological mediation in ocean crust alteration: how deep is the deep biosphere? Earth Planet. Sci. Lett. 166, 97-103.

Heberling, C., Lowell, R. P., Liu, L., and Fisk, M. R. (2010). Extent of the microbial biosphere in the oceanic crust. Geochem. Geophys. Geosyst. 11, $1-15$.

Huber, J. A., Johnson, H. P., Butterfield, D. A., and Baross, J. A. (2006). Microbial life in ridge flank crustal fluids. Environ. Microbiol. 8, 88-99.

Hutnak, M., Fisher, A. T., Zühlsdorff, L., Spiess, V., Stauffer, P. H., and Gable, C. W. (2006). Hydrothermal recharge and discharge guided by basement outcrops on $0.7-3.6 \mathrm{Ma}$ seafloor east of the Juan de Fuca Ridge: observations and numerical models. Geochem. Geophys. Geosyst. 7, 1-36.

Imachi, H., Aoi, K., Tasumi, E., Saito, Y., Yamanaka, Y., Saito, Y., Yamaguchi, T., Tomaru, H., Takeuchi, R., Morono, Y., Inagaki, F., and Takai, K. (2011). Cultivation of methanogenic community from subseafloor sediments using a continuous-flow bioreactor. ISME J. 5, 1913-1925.

Inagaki, F., Suzuki, M., Takai, K., Oida, H., Sakamoto, T., Aoki, K., Nealson, K. H., and Horikoshi, K. (2003). Microbial communities associated with geological horizons in coastal subseafloor sediments from the sea of Okhotsk. Appl. Environ. Microbiol. 69, 7224-7235.

Johnson, H. P., Baross, J. A., and Bjorklund, T. A. (2006). On sampling the upper crustal reservoir of the NE Pacific Ocean. Geofluids 6, 251-271.

Johnson, H. P., and Pruis, M. J. (2003). Fluxes of fluid and heat from the oceanic crustal reservoir. Earth Planet. Sci. Lett. 216, 565.

Kaye, J. Z., Sylvan, J. B., Edwards, K. J., and Baross, J. A. (2011). Halomonas and Marinobacter ecotypes from hydrothermal vent, subseafloor and deep-sea environments. FEMS Microbiol. Ecol. 75, 123-133.

Kendall, M. M., Liu, Y., SieprawskaLupa, M., Stetter, K. O., Whitman, W. B., and Boone, D. R. (2006). Methanococcus aeolicus sp. nov., a mesophilic, methanogenic archaeon from shallow and deep marine sediments. Int. J. Syst. Evol. Microbiol. 56, 1525-1529.

Köpke, B., Wilms, R., Engelen, B., Cypionka, H., and Sass, H. (2005).
Microbial diversity in coastal subsurface sediments: a cultivation approach using various electron acceptors and substrate gradients. Appl. Environ. Microbiol. 71, 7819-7830.

Kuever, J., Könneke, M., Galushko, A., and Drzyzga, O. (2001). Reclassification of Desulfobacterium phenolicum as Desulfobacula phenolica comb. nov. and description of strain SaxT as Desulfotignum balticum gen. nov., sp. nov. Int. J. Syst. Evol. Microbiol. 51, 171-177.

Lauro, F. M., McDougald, D., Thomas, T., Williams, T. J., Egan, S., Rice, S., DeMaere, M. Z., Ting, L., Ertan, H., Johnson, J., Ferriera, S., Lapidus, A., Anderson, I., Kyrpides, N., Munk, A. C., Detter, C., Han, C. S., Brown, M. V., Robb, F. T., Kjelleberg, S., and Cavicchioli, R. (2009). The genomic basis of trophic strategy in marine bacteria. Proc. Natl. Acad. Sci. U.S.A. 106, 15527-15533.

Lee, Y.-J., Wagner, I., Brice, M., Kevbrin, V., Mills, G., Romanek, C., and Wiegel, J. (2005). Thermosediminibacter oceani gen. nov., sp. nov. and Thermosediminibacter litoriperuensis sp. nov., new anaerobic thermophilic bacteria isolated from Peru Margin. Extremophiles 9, 375-383.

Lever, M. A., Alperin, M., Engelen, B., Inagaki, F., Nakagawa, S., Steinsbu, B. O., Teske, A., and IODP Expedition 301 Scientists. (2006). Trends in basalt and sediment core contamination during IODP Expedition 301. Geomicrobiol. J. 23, 517-530.

Lipp, J. S., Morono, Y., Inagaki, F., and Hinrichs, K. U. (2008). Significant contribution of Archaea to extant biomass in marine subsurface sediments. Nature 454, 991-994.

Mangelsdorf, K., Zink, K. G., Birrien, J. L., and Toffin, L. (2005). A quantitative assessment of pressure dependent adaptive changes in the membrane lipids of piezosensitive deep sub-seafloor bacterium. Org. Geochem. 36, 1459-1479.

McCollom, T. M., and Bach, W. (2009). Thermodynamic constraints on hydrogen generation during serpentinization of ultramafic rocks. Geochim. Cosmochim. Acta 73, 856-875.

Mikucki, J. A., Liu, Y., Delwiche, M., Colwell, F. S., and Boone, D. R. (2003). Isolation of a methanogen from deep marine sediments that contain methane hydrates, and description of Methanoculleus submarinus sp. nov. Appl. Environ. Microbiol. 69, 3311-3316.

Morgulis, A., Coulouris, G., Raytselis, Y., Madden, T. L., Agarwala,
R., and Schäffer, A. A. (2008) Database indexing for production MegaBLAST searches. Bioinformatics 15, 1757-1764.

Mori, K., Tsurumaru, H., and Harayama, S. (2010). Iron corrosion activity of anaerobic hydrogen-consuming microorganisms isolated from oil facilities. $J$. Biosci. Bioeng. 110, 426-430.

Motamedi, M., and Pedersen, K. (1998). Desulfovibrio aespoeensis sp. nov. a mesophilic sulfate-reducing bacterium from deep groundwater at Äspö hard rock laboratory, Sweden. Int. J. Syst. Bacteriol. 48, 311-315.

Nakagawa, S., Inagaki, F., Suzuki, Y. Steinsbu, B. O., Lever, M. A., Takai, K., Engelen, B., Sako, Y., Wheat, C. G., Horikoshi, K., and IODP Expedition(301)Scientists. (2006). Microbial community in black rust exposed to hot ridge flank crustal fluids. Appl. Environ. Microbiol. 72, 6789-6799.

Nealson, K. H., Inagaki, F., and Takai, K. (2005). Hydrogen-driven subsurface lithoautotrophic microbial ecosystems (SLiMEs): do they exist and why should we care? Trends Microbiol. 13, 405-410.

Orcutt, B. N., Bach, W., Becker, K., Fisher, A. T., Hentscher, M., Toner B. M., Wheat, C. G., and Edwards, K. J. (2010). Colonization of subsurface microbial observatories deployed in young ocean crust. ISME J. 5, 692-703.

Overmann, J., and Tuschak, C. (1997). Phylogeny and molecular fingerprinting of green sulfur bacteria. Arch. Microbiol. 167, 302-309.

Pankhania, I. P. (1988). Hydrogen metabolism in sulphate-reducing bacteria and its role in anaerobic corrosion. Biofouling 1, 27-47.

Parkes, R. J., Cragg, B. A., Bale, S. J., Getliff, J. M., Goodman, K., Rochelle, P. A., Fry, J. C., Weightman, A. J., and Harvey, S. M. (1994). Deep bacterial biosphere in Pacific Ocean sediments. Nature 371, 410-413.

Parkes, R. J., Cragg, B. A., Bale, S. J., Goodman, K., and Fry, J. C. (1995). A combined ecological and physiological approach to studying sulfate reduction within deep marine sediment layers. J. Microbiol. Methods 23, 235-249.

Parkes, R. J., Linnane, C. D., Webster, G., Sass, H., Weightman, A. J., Hornibrook, E. R. C., and Horsfield, B. (2011). Prokaryotes stimulate mineral $\mathrm{H}_{2}$ formation for the deep biosphere and subsequent thermogenic activity. Geology 39, 219-222.
Pedersen, K. (1997). Microbial life in deep granitic rock. FEMS Microbiol. Rev. 20, 399-414.

Pedersen, K. (2000). Exploration of deep intraterrestrial microbial life: current perspectives. FEMS Microbiol. Lett. 185, 9-16.

Ramamoorthy, S., Sass, H., Langner, H., Schumann, P., Kroppenstedt, R. M., Spring, S., Overmann, J., and Rosenzweig, R. F. (2006). Desulfosporosinus lacus sp nov., a sulfate-reducing bacterium isolated from pristine freshwater lake sediments. Int. J. Syst. Evol. Microbiol. 56, 2729-2736.

Roussel, E. G., Bonavita, M. A. C., Querellou, J., Cragg, B. A., Webster, G., Prieur, D., and Parkes, R. J. (2008). Extending the sub-sea-floor biosphere. Science 320, 1046-1046.

Rouxel, O., Ono, S., Alt, J., Rumble, D., and Ludden, J. (2008). Sulfur isotope evidence for microbial sulfate reduction in altered oceanic basalts at ODP Site 801. Earth Planet. Sci. Lett. 268, 110-123.

Santelli, C. M., Orcutt, B. N., Banning, E., Bach, W., Moyer, C. L., Sogin, M. L., Staudigel, H., and Edwards, K. J. (2008). Abundance and diversity of microbial life in ocean crust. Nature 453, 653-656.

Sass, H., and Cypionka, H. (2004). Isolation of sulfate-reducing bacteria from the terrestrial deep subsurface and description of Desulfovibrio cavernae sp. nov. Syst. Appl. Microbiol. 27, 541-548.

Smith, A., Popa, R., Fisk, M., Nielsen, M., Wheat, C. G., Jannasch, H. W., Fisher, A. T., Becker, K., Sievert, S. M., and Flores, G. (2011). In situ enrichment of ocean crust microbes on igneous minerals and glasses using an osmotic flow-through device. Geochem. Geophys. Geosyst. 12, 1-19.

Steinsbu, B. O., Thorseth, I. H., Nakagawa, S., Inagaki, F., Lever, M. A. Engelen, B., Øvreås, L., and Pedersen, R. B. (2010). Archaeoglobus sulfaticallidus sp. nov., a novel thermophilic and facultatively lithoautotrophic sulfate-reducer isolated from black rust exposed to hot ridge flank crustal fluids. Int. J. Syst. Evol. Microbiol. 60, 2745-2752.

Stevens, H., Brinkhoff, T., and Simon, M. (2005). Composition of freeliving, aggregate-associated and sediment surface-associated bacterial communities in the German Wadden Sea. Aquat. Microb. Ecol. 38, 15-30.

Stevens, T. (1997). Lithoautotrophy in the subsurface. FEMS Microbiol. Rev. 20, 327-337.

Stevens, T. O., and McKinley, J. P. (1995). Lithoautotrophic microbial 
ecosystems in deep basalt aquifers. Science 270, 450-455.

Straskrabová, V. (1983). The effect of substrate shock on populations of starving aquatic bacteria. J. Appl. Bacteriol. 54, 217-224.

Süss, J., Engelen, B., Cypionka, H., and Sass, H. (2004). Quantitative analysis of bacterial communities from Mediterranean sapropels based on cultivation-dependent methods. FEMS Microbiol. Ecol. 51, 109-121.

Thorseth, I. H., Torsvik, T., Furnes, H., and Muehlenbachs, K. (1995). Microbes play an important role in the alteration of oceanic crust. Chem. Geol. 126, 137-146.

Toffin, L., Bidault, A., Pignet, P., Tindall, B. J., Slobodkin, A., Kato, C., and Prieur, D. (2004a). Shewanella profunda sp. nov., isolated from deep marine sediment of the Nankai trough. Int. J. Syst. Evol. Microbiol. 54, 1943-1949.

Toffin, L., Webster, G., Weightman, A. J., Fry, J. C., and Prieur, D. (2004b). Molecular monitoring of culturable bacteria from deep-sea sediment of the Nankai trough, Leg 190 Ocean Drilling Program. FEMS Microbiol. Ecol. 48, 357-367.

Toffin, L., Zink, K., Kato, C., Pignet, P., Bidault, A., Bienvenu, N., Birrien, J. L., and Prieur, D. (2005). Marinilactibacillus piezotolerans sp. nov., a novel marine lactic acid bacterium isolated from deep sub-seafloor sediment of the Nankai trough. Int. J. Syst. Evol. Microbiol. 55, 345-351.

Wheat, C. G., Elderfield, H., Mottl, M. J., and Monnin, C. (2000). Chemical composition of basement fluids within an oceanic ridge flank: implications for alongstrike and across-strike hydrothermal circulation. J. Geophys. Res. 105, 13437-13447.

Wheat, C. G., and Mottl, M. J. (1994). Hydrothermal circulation, Juan de Fuca Ridge eastern flank: factors controlling basement water composition. J. Geophys. Res. 99, 3067-3080.
Whitman, W. B., Coleman, D. C., and Wiebe, W. J. (1998). Prokaryotes: the unseen majority. Proc. Natl. Acad. Sci. U.S.A. 95, 6578-6583.

Widdel, F., and Bak, F. (1992). "Gram-negative mesophilic sulfatereducing bacteria," in The Prokaryotes, eds A. Balows, H. G. Trüper, M. Dworkin, W. Harder, and K. H. Schleifer (New York: SpringerVerlag), 3352-3378.

Wilms, R., Köpke, B., Sass, H., Chang, T. S., Cypionka, H., and Engelen, B. (2006a). Deep biosphere-related bacteria within the subsurface of tidal flat sediments. Environ. Microbiol. 8, 709-719.

Wilms, R., Sass, H., Köpke, B., Köster, J., Cypionka, H., and Engelen, B. (2006b). Specific bacterial, archaeal, and eukaryotic communities in tidal-flat sediments along a vertical profile of several meters. Appl. Environ. Microbiol. 72, 2756-2764.

Conflict of Interest Statement: The authors declare that the research was conducted in the absence of any commercial or financial relationships that could be construed as a potential conflict of interest.

Received: 15 November 2011; paper pending published: 16 December 2011; accepted: 06 February 2012; published online: 20 February 2012.

Citation: Fichtel K, Mathes F, Könneke $M$, Cypionka $H$ and Engelen $B$ (2012) Isolation of sulfate-reducing bacteria from sediments above the deepsubseafloor aquifer. Front. Microbio. 3:65. doi: 10.3389/fmicb.2012.00065

This article was submitted to Frontiers in Extreme Microbiology, a specialty of Frontiers in Microbiology.

Copyright (C) 2012 Fichtel, Mathes, Könneke, Cypionka and Engelen. This is an open-access article distributed under the terms of the Creative Commons Attribution Non Commercial License, which permits non-commercial use, distribution, and reproduction in other forums, provided the original authors and source are credited. 